\title{
THE
}

9-2013

\section{Mothers, Daughters, and the Transmission of Memory in Documentaries Directed by Women of Maghrebi Origin in France}

Leslie Kealhofer-Kemp

University of Rhode Island, Ikealhofer@uri.edu

Follow this and additional works at: https://digitalcommons.uri.edu/ml_facpubs

The University of Rhode Island Faculty have made this article openly available.

Please let us know how Open Access to this research benefits you.

This is a pre-publication author manuscript of the final, published article.

Terms of Use

This article is made available under the terms and conditions applicable towards Open Access

Policy Articles, as set forth in our Terms of Use.

\section{Citation/Publisher Attribution}

Kealhofer-Kemp, Leslie. "Mothers, daughters, and the transmission of memory in documentaries directed by women of Maghrebi origin in France." Studies in French Cinema, vol. 13, no. 3, 2013, pp. 227-240.

http://dx.doi.org/10.1386/sfc.13.3.227_1

Available at: http://dx.doi.org/10.1386/sfc.13.3.227_1

This Article is brought to you for free and open access by the Modern and Classical Languages and Literatures at DigitalCommons@URI. It has been accepted for inclusion in Modern and Classical Languages and Literatures Faculty Publications by an authorized administrator of DigitalCommons@URI. For more information, please contact digitalcommons-group@uri.edu. 


\title{
Mothers, daughters, and the transmission of memory in documentaries directed by women of Maghrebi origin in France
}

Leslie Kealhofer, University of Rhode Island

\begin{abstract}
This article compares the treatment of memory and the transmission of memory in Yamina Benguigui's Mémoires d'immigrés: l'héritage maghrébin (1997) with the treatment of these themes in five other documentaries directed by Maghrebi-French women - all of which were released after Mémoires d'immigrés: Yasmina Kherfi's Mes voisines mes copines (2002), Djamila Sfaxi’s À ma mère (2003), Rahma Benhamou El Madani's Du côté de chez soi (2003), Soraya Nini's 24 heures dans la Life de ma mère (2007) and Fatima Sissani's La langue de Zahra (2011). It argues that in contrast to Benguigui's foregrounding of collective experiences of Maghrebi migrant women in Mémoires d'immigrés, these five documentaries highlight the specificity of the memories and experiences of the directors' mothers and in doing so problematize the very idea that there exists a collective trajectory or set of experiences with regard to Maghrebi migrants in France. When considered together, these films reflect a shift away from the universalizing and collective view of Maghrebi migration that is set forth in Benguigui's documentary.
\end{abstract}

\section{Keywords}

Yamina Benguigui 


\section{Mémoires d'immigrés: l'héritage maghrébin}

documentary film

mother

collective memory

immigration

There are as many immigrant stories as there are immigrants. (Fatima Sissani)

\section{Introduction}

When film-maker (and now government minister) Yamina Benguigui's documentary Mémoires d'immigrés: l'héritage maghrébin/Immigrant Memories: the North African Inheritance was broadcast on the private television network Canal+ in 1997, it received widespread popular and critical acclaim, and its success was also reflected by the film's release in theatres in 1998. The documentary is composed of three 52-minute segments of interviews entitled 'Les Pères'/‘The Fathers', 'Les Mères'/‘The Mothers', and 'Les Enfants'/‘The Children. As Carrie Tarr (with Brigitte Rollet) has noted, the film 'fill[ed] a major gap in the French cinematographic landscape by devoting space to first generation immigrants from the Maghreb, whose story ha[d] rarely been seen or heard before' (2001: 51). The designation ‘first-generation' immigrants from the Maghreb refers to the first wave of Muslim migrants from Morocco, Algeria, and Tunisia (born under French colonial rule) to settle in France in large numbers. First-generation men came to France (or were recruited) in the 1950s and 1960s to fulfil a need for manual labourers during France's post-war economic boom, while first-generation women tended 
to join their husbands in the 1960s and 1970s, as part of a process known as $l e$ regroupement familial (or family reunification).

Sylvie Durmelat characterizes Benguigui's work in Mémoires d'immigrés as that of a 'memory entrepreneuse', a concept proposed by Gérard Noiriel (who drew on the work of Max Weber and Maurice Halbwachs). As Durmelat explains:

According to Noiriel (1995, p. 380), for a collective memory to emerge, individual recollections must necessarily be objectivized by a process of naming, fixed in writing, but also continuously recalled by monuments and other forms of commemoration. Individual actors can thus link their personal experiences to a shared, collective representation of the past. In order to do this, the role of 'memory entrepreneurs' is crucial, for it is they who choose what individual experiences best represent their cause and then transform these into collective memory (2000: 173).

Similarly, for Isabelle McNeill, in Mémoires d'immigrés, Benguigui 'attempt[s] to represent the common strands of experience shared by the community of North African immigrants living in France' (2010: 103).

The aim of this article is to compare the treatment of memory and the transmission of memory in Mémoires d'immigrés with the treatment of these themes in five other documentaries directed by Maghrebi-French women, all of which were released after Mémoires d'immigrés (between 2002 and 2011) and have yet to be the subject of scholarly attention. These films all focus to a significant extent on the 
directors' mothers and engage with the theme of memory, some directly, as in the case of Mémoires d'immigrés, and others more indirectly. The films in question are: Yasmina Kherfi's Mes voisines mes copines/My Neighbours, My Girlfriends (2002, 26'), Djamila Sfaxi's À ma mère/To My Mother (2003, 21'), Rahma Benhamou El Madani's Du côté de chez soi/Near Where One is From (2003, 57'), Soraya Nini's 24 heures dans la Life de ma mère/24 Hours in my Mother's Life (2007, 36') and Fatima Sissani's La langue de Zahra/Zahra's Mother Tongue (2011, 93').

My analysis will consider the extent to which the documentary films in question enter into dialogue with Mémoires d'immigrés and offer new perspectives with regard to the question of memory and the cinematic representations of first-generation Maghrebi women in France. I will highlight differences that exist between Benguigui's film and the other documentaries with regard to the context and material conditions of making the films, and the impact of these choices on the treatment of memory. While it can be maintained that all of these documentaries, including Mémoires d'immigrés, have a significant point in common - namely encouraging an awareness of and appreciation for the experiences of migrant women from the Maghreb in France - there are significant differences between Benguigui's documentary and the five documentaries produced after it. I will argue that in contrast to Benguigui's foregrounding of collective experiences in Mémoires d'immigrés, these documentaries highlight the specificity of the memories and experiences of the directors' mothers, thus problematizing the very idea that there exists a collective trajectory or set of experiences with regard to Maghrebi migrants in France. When considered together, these films reflect a shift away from the universalizing and collective view of Maghrebi migration that is set forth in Benguigui's documentary. 
This article will be divided into two parts: first, I will briefly lay out the treatment of the theme of memory in the section of Benguigui's documentary entitled 'Les Mères', since it will serve as the main point of comparison for the five other documentaries. Then, I will analyse the ways in which the remaining films approach the theme of memory and the transmission of memory within the context of the mother-daughter dynamic.

\section{Mémoires d'immigrés: L'héritage maghrébin}

Benguigui has explained that in making her documentary, she hoped to create a place for Maghrebi migrants and their descendants in the collective memory of France (1997a). Durmelat has argued that Benguigui's film has been successful in this regard, constructing 'a place for the collective memory of Maghrebi immigration in France, a memory that has hitherto been marked by national amnesia (Noiriel 1995), the silence of the parents, and the ignorance, or rather, the indifference of French society' (2000: 171). The amnesia and silences are rooted notably in France's colonial past and postcolonial present, and in particular the bitter eight year Algerian war of independence, which ended in 1962 (cf. Stora 1998). Crucial to her success in bringing these migrant memories into the public spotlight in the form of filmed interviews, Benguigui maintains, was her choice to clearly position herself during the interview process as the daughter of Maghrebi migrants, thereby setting up an intergenerational transmission of memory (although she did not interview her own parents, she did interview people of her parents' generation) (Benguigui 1997a). As McNeill has argued, in making Mémoires d'immigrés, 'Benguigui has drawn on a wide range of testimony, as well as numerous archival 
sources, in order to distil something of a collective past that has an emotional resonance for her personally' (2010: 104). The creation of this film involved considerable preparation, editing, and a large film crew, and it also benefited from a budget that was much larger than those of the five other documentaries discussed below. Specifically, the process involved ' 350 interviews, two years of preparation, nine months of editing, 600 hours of rushes and a budget of fifty million francs' (Durmelat 2000: 171).

The second part of Mémoires d'immigrés focuses on the experiences of Maghrebi migrant women in France. Six Maghrebi women are interviewed in pairs, and two women are interviewed alone. Benguigui does not appear in the interviews, nor is her voice heard, as she erased signs of her presence from the film during post-production. The emphasis placed on collective experiences is reflected by the inclusive nature of the title - 'Les Mères' - and is clearly illustrated in the opening sequence, which begins with close-up and extreme close-up shots of the faces of Maghrebi women in slow motion. Edited into these shots are black and white family photographs as well as medium and medium close-up shots of women in their homes (in some cases with a family member). These images are paired with a soundtrack that serves to give the women a common voice and implicitly suggests that 'les mères' have shared a similar set of experiences: the spectator hears an emotion-laden female voice singing in Arabic about the beauty of the country left behind, exile, memories of the past, and the desire to return to her country one day. The lyrics are also subtitled in French, which ensures that the meaning is clearly communicated to non-Arabic speaking spectators.

The content of the contemporary interviews with Maghrebi women that follow this introductory sequence also serves to point to a collective memory of first-generation 
women in France. The women speak almost exclusively in French, and the interviews focus to a large extent on memories of their arrival and often difficult first years in France. Recurrent themes include the women's experiences as immigrants, as women in a patriarchal culture, and as mothers raising their children in a foreign culture, far from the family network they left behind. The first women featured, Mekia Gomri and Aldjia Bouachera, speak of the disillusion they felt when they arrived in France and realized that it was not the paradise that they had imagined. They explain their decision to remain in France permanently, rather than return to their country of origin, stating that it is because their children are there, sentiments echoed later in the film by Khira, Yamina Amri, and Khadija. Khira and Yamina Baba Aïssa, interviewed individually, describe the trauma of their arranged marriages and state that it is something that they would never impose on their own daughters. Yamina Baba Aïssa explains that it was only after divorcing her husband that she finally felt free. The topic of personal independence is also discussed by Zohrra - interviewed in her café in Paris - who says that personal independence came with starting her own business.

Edited into these sequences are interviews with representatives of the French state who were in office during the years the women migrated to France, as well as black and white photographs and archive videos of Maghrebi women in shantytowns (where many first-generation women lived upon their arrival in France). For McNeill, the inclusion of archive images and photographs with contemporary interviews in Mémoires d'immigrés is particularly significant, and she views it as 'the interweaving of images past and present to evoke a virtual realm of collective memory' (2010: 111). As McNeill argues: 
[T] hese images of the past tend not to be attributed to named individuals or even places. Although the credits at the end of each part of the trilogy list the sources of the archive material, within the film the images circulate anonymously, often reappearing across different sections. Even the family photographs depend on the spectator's recognition of faces marked by the passage of time. Photographs alternate with archive footage in illustrating the memories described on the soundtrack. This creates persistent indeterminacy, in which particular images are detached from the specificity of their referents and participate in a more collective evocation of past possibilities. (2010: 105)

I am not suggesting that Benguigui's film glosses over all differences that exist between the women interviewed or fails to acknowledge any individual trajectories (the women settled in different parts of France, for example), but the way in which this part of the documentary is constructed encourages the spectator to see the common elements in the experiences of 'les mères'. Furthermore, this collective narrative is strengthened by significant omissions from Benguigui's film. As Tarr (with Rollet) has argued, 'in her desire for reconciliation and acceptance, Benguigui deliberately rejects or minimizes material that might be divisive (testimonies about contemporary violence and disturbances in the banlieue, the heritage of the Algerian war, the role of Islam, differences within the community)' (2001: 152). For example, Mémoires d'immigrés does not address the controversial subject of the Islamic headscarf (cf. Kealhofer 2011). Moreover, '[t]he Maghrebi populations settled in France since the first half of the twentieth century go unmentioned, as do non-economic migrants like the harkis 
(Algerian soldiers who fought for the French during the Algerian war of independence) and their families, the inclusion of which would render the notion of a Maghrebi heritage less self-evident' (Durmelat 2000: 176). As will be discussed below, some of these omissions are treated, at least to a certain degree, in the documentaries produced after Mémoires d'immigrés.

\section{Mother-daughter films and memory after Mémoires d'immigrés}

The next part of this article will examine the treatment of memory in documentaries directed by Maghrebi-French women, all of which were produced after Mémoires d'immigrés. I would like to suggest that in their treatment of the theme of memory, these films reflect a clear shift away from the focus on a collective narrative that is set forth in Benguigui's film. In two of the films, a key preoccupation is the creation of an intergenerational transmission of memory from mother to daughter, which enables the daughter to better understand not only her mother, but also aspects of her own identity. Two of the other films focus to a large extent on documenting the present day lives of first-generation Maghrebi women in France, and in particular, certain customs or traditions, such as recipes or traditional dress, that they have maintained from their country of origin. Here, the directors document moments in the daily lives of their mothers and inscribe them in cinematic form, and these snapshots will then be transmitted to spectators, present and future. All of the films in my corpus are involved in this kind of transmission to a certain extent, but the films in this second group differ in that documenting varied aspects of the Maghrebi women's lives in the present is their primary focus. The final film takes as a point of departure the transmission of memory 
and culture through the prism of the Kabyle language. In all of these films, the motherdaughter relationship plays an integral role in the transmission of memory.

Du côté de chez soi by El Madani, and À ma mère, by Sfaxi, involved the directors' struggle with coming to terms with and developing a better understanding of their own heritage and identity, and the need to know more about their parents, and in particular their mothers. Like Benguigui, these daughters looked to their mothers - and the medium of cinema - in the process. For El Madani and Sfaxi, the voids to be filled are not located primarily at the level of the collective, but rather, at a much more personal level, within the women's families. Thus only the directors' parents (and especially their mothers), could fill these gaps. As El Madani told me in 2010, her decision to make such a personal documentary and to film her parents in France and Morocco also had an impact on the cinematographic techniques that she employed: 'I could have told this story in a way that was much more sober, and more measured, with static shots, with a crew, $[\ldots]$ but it's not the case. It's something much more instinctive, spontaneous, and personal' (1 June 2010 interview). Similarly, Sfaxi had to adapt the techniques that she initially planned to use when she realized that her mother was not expressing herself openly in the presence of the film crew. She thus decided to do all of the camera and sound work herself (10 June 2010 interview).

El Madani and Sfaxi's films document experiences and struggles that diverge in significant ways from the collective set of experiences that are highlighted in Benguigui's documentary, and they problematize the very notion that there exists a collective trajectory or set of experiences with regard to Maghrebi migrants in France, as Mémoires d'immigrés would seem to suggest. El Madani's documentary (co-produced in the post- 
production phase by Jean-Pierre and Luc Dardenne), highlights the atypical migratory path of El Madani's parents, who first emigrated from Morocco to Algeria (where El Madani was born) for economic reasons, only to leave Algeria for France shortly after Algerian independence in 1962. As the documentary highlights, El Madani's parents have very mixed emotions about Algeria. They supported the Algerian struggle for independence, and it was there that some of their children were born, so they do maintain certain affective ties to the country, yet their memories of their time there are by no means all positive; they ultimately left the country post-independence after facing discrimination due to their Moroccan origins and being accused of taking jobs from Algerians. It was this rejection that motivated the family's migration to France. El Madani told me that it was through the medium of cinema, and the transmission of memory from mother to daughter (and father to daughter, to a certain extent) that she hoped to achieve two main objectives: first, to come to a better understanding of her parents' desire to retire in Morocco (a country that she did not know); and second, to explore her family's connection to Algeria. As she explained, 'the film was also to rediscover my ties to Algeria', a taboo subject in her family, for the reasons mentioned above (1 June 2010 interview). The film opens with a sequence of tracking shots of vineyards and châteaux near Bordeaux, which are paired with an extradiegetic song in Arabic (subtitled in French) that evokes the themes of poverty and exile. While the song foreshadows the theme of exile in the film, it does not serve to link the experiences of the director's parents to a larger, collective experience, as does the song at the beginning of Mémoires d'immigrés. The interviews with the director's parents, in 
which they describe being treated like outsiders wherever they go, reveal that their experiences do not fit into the collective narrative advanced in Benguigui's film.

The second documentary involving the intersection of the transmission of memory and the daughter/film-maker's heritage is Djamila Sfaxi's $\grave{A}$ ma mère, which was produced as part of a workshop with Altermédia, an organization whose projects are funded, in part, by the European Social Fund and the city of Paris (Altermédia). The film centres on Sfaxi's mother - originally from the Kabylia region of Algeria - who is a softspoken woman suffering from a lack of self-confidence. She speaks very little French and only rarely ventures outside the family apartment, despite having lived in France for 36 years. She explains that since her husband rarely allowed her to go out on her own and she stayed home to raise their children, she never learned to speak French or even to find her way around Paris. Moreover, she says, while she was fortunate to have never lived in the insalubrious shantytowns in which many first-generation Maghrebis resided upon their arrival in France (shantytowns that feature prominently in the archive images and footage edited into Benguigui's film), the relative isolation in which she lived meant that she had few chances to meet friends and did not meet any other women who spoke her language. During the interview with her daughter - in which she speaks almost exclusively Kabyle, with a speckling of French, and her daughter speaks French - she confides that even after so many years in France, she is still terrified to speak French and lacks the confidence to learn.

The interview of Sfaxi's mother is notably different from the interviews of 'les mères' in Mémoires d'immigrés. First, as mentioned above, the interviews in Benguigui's film are conducted almost exclusively in French, which implicitly points to the extent to 
which the women have integrated into France. Second, while the interviews in Benguigui's documentary do not avoid showing the challenges faced by many of the women or their struggles for personal independence, they nonetheless share a common element: the interviews highlight how the women's struggles were eventually overcome, resulting in newfound freedoms and independence for the women. By contrast, in $\grave{A} m a$ mère, Sfaxi's mother - who is interviewed in her kitchen, where she feels at ease describes ongoing struggles, including loneliness, isolation, and difficulty communicating in French. One cannot help but draw a parallel between Sfaxi's mother and Zouina, the fictional protagonist of Benguigui's feature film Inch'Allah dimanche/Inch 'Allah Sunday (2001), which is set in the 1970s. ${ }^{1}$ Zouina is a prisoner in her home and virtually cut off from the outside world. Unlike Sfaxi's mother, however, the protagonist in Benguigui's film is determined to break out of the confines of her home and eventually obtains newfound freedoms after she stands up to her husband and mother-in-law.

In El Madani and Sfaxi's films, the documentary project and the mother-daughter transmission of memory filled a void in each daughter's knowledge of her mother's past. In turn, this process played a significant role in the daughter's coming to terms with her own identity struggle and sense of self. In a voice-over commentary near the conclusion of $\grave{A}$ ma mère, Sfaxi confirms that by learning about her mother's past and gaining access to some of her memories, she has come to a better understanding of both her mother and especially her mother's submissiveness, which the director now attributes to a lack of education rather than a character flaw - and herself, and in particular her fierce sense of independence and desire to travel the world. 
Kherfi's Mes voisines mes copines (2002) and Nini's 24 heures dans la Life de ma mère (2007) engage with memory and the transmission of memory in a way that is very different from both El Madani and Sfaxi's films and Mémoires d'immigrés. While memories of the women's country of origin and first years in France may be evoked in Kherfi's and Nini's documentaries, they focus on the daily lives of Maghrebi women in contemporary France. Kherfi's film, produced as part of a workshop with Les Ateliers Varan in Paris, follows not only the director's mother, Dabhia, but also her mother's group of friends - Maghrebi women whom both mother and daughter have known for many years. Nini's film, a low-budget production, features one woman: Nini's mother, Fatma. The film follows Fatma as she goes about her daily routine, cooking, watching the news on television, entertaining friends, praying and shopping. At times, both of these films adopt what Bill Nichols has termed an observational approach to documentary. This comes through in sequences that document the daily activities of these women in their homes and neighbourhoods and during interactions with friends and neighbours. The scenes are 'observational' in the sense that they '[stress] the nonintervention of the filmmaker' (Nichols 1991: 38) and 'are characterized by indirect address, speech overheard rather than heard since the social actors engage with one another rather than speak to the camera' (Nichols 1991: 39).

In foregrounding the women's relationships and place in their communities (in the geographic, not strictly ethnic, sense), the films emphasize the extent to which the women's lives are rooted in their neighbourhood in France and have been for many years. This idea is reinforced with particular clarity by Kherfi's mother and her mother's friend, Madame Ouici, as they speak in fond terms about their neighbourhood and clearly 
consider it to be their home. A similar idea is highlighted visually in a short sequence in Nini's film in which the director's mother's ID card, national health care card, grocery store card and others - all reminders of her life in France - are dropped one by one onto the kitchen table. A parallel can be drawn here between these two films and Mémoires d'immigrés, in the sense that they all suggest that while the women featured in the films may maintain certain cultural and affective ties to their country of origin, they have also made a life in France and have no intention of leaving.

But if these films focus to a large degree on the present, how exactly does the treatment of memory come in? Whereas in the two documentaries previously discussed, memories are passed from mother to daughter principally through discussions of the past, in Mes voisines mes copines and 24 heures dans la Life de ma mère the transmission of memory functions in another way entirely, and the films can be seen to have a different goal. In both documentaries, the directors film their respective mother's daily activities and in doing so preserve in cinematic form not only their mother's unique personalities and points of view, but also, and significantly, certain traditions from their country of origin that form a part of their daily lives in France. For example, all three of the women interviewed in Mes voisines mes copines are filmed in their kitchens in the presence of one or more of their daughters, while preparing dishes that they learned to make in their country of origin. During each of these sequences, the camera dwells on the women's hands and the food that they prepare, thus capturing a visual memory of the women's handiwork. The importance of preserving these images is reinforced by verbal exchanges between the women and their daughters, which reveal that the daughters do not know how (or do not take the time) to prepare these dishes and therefore will likely not keep 
these culinary traditions alive in the future. Madame Ouici prepares a chorba soup for her adult daughter to eat during Ramadan, for example, and as she hands over the soup, she turns to the camera and explains that she always makes this soup for her daughter, since her daughter is not used to making it. When Dabhia prepares pastries and tells her daughter that it is not difficult to do, her daughter responds by saying that she does not have the time to make them. Similarly, Madame Kallouche is filmed while kneading bread, and when she states that her daughters do not know how to make a couscous or anything else, one of her daughters responds by saying that it is because they do not have time. Nini also uses close-up shots of her mother's hands at work to foreground her mother's knowledge in the kitchen, and she employs two additional techniques: on-screen texts detail the ingredients that Fatma uses to prepare a dish; and a four-way split screen captures Fatma's actions at different stages of cooking a couscous.

Kherfi explained to me that she was motivated to make her film not only to shed light on women who are not often the subject of cinematic cultural productions in France, but even more importantly, to document things common to her mother's generation - like the culinary knowledge mentioned above - that would otherwise be lost with the passage of time. As she explained, 'these are images that won't be seen again' in the streets and in homes in France (12 May 2010 interview). Furthermore, by filming both mothers and daughters together, these documentaries also show that the Maghrebi-French daughters do not dress like their mothers - they do not wear the brightly coloured dresses or headscarves that their mothers wear - nor do they have the same relationship to their mothers' native language, which is not their primary language. 
In carrying out their cinematic projects, Kherfi and Nini are involved in a transmission of memory: transmitting images of first-generation women, which are effectively memories of their mothers captured in documentary form, to the films' implied spectators, present and future. It is worth underscoring that these films are not simply home videos, but documentaries, and thus aimed at a diverse audience. In inscribing the images and voices of their mothers in documentary form, the daughters/directors contribute to creating a place for Maghrebi migrant women in France. The films suggest that while Maghrebi women of this generation maintain certain ties to their culture of origin, they should also be seen as a part of France's past and present. While Benguigui's film may share a similar purpose with these films - creating a place for Maghrebi migrants and their descendants in France - Kherfi and Nini's films do this by focusing on the specificity of individual trajectories, thus challenging a universalizing vision of the Maghrebi migrant experience.

Figure 1: The poster for La langue de Zahra (http://www.lemag.ma).

The final film in my corpus is Sissani's feature length documentary, La langue de Zahra. It was released in 2011 and has been selected for numerous international film festivals. The documentary received funding from sources such as the CNC (National Cinema Centre) and 1'Acsé (National Agency for Social Cohesion and Equal Opportunities), but it is notable that the film's initial budget of roughly 8000 Euros came from donations from Sissani's family and friends (Sissani 2013). Shot in France and Algeria, La langue 
de Zahra follows Sissani's mother, Zahra, who emigrated from the Kabylia region of Algeria in the 1960s. It focuses on Zahra's poetic use of the Kabyle language and the strong ties to her cultural roots and native language that she has made a conscious effort to preserve over the years. In its treatment of memory, this film shares common points with the two groups just discussed, as well as with Mémoires d'immigrés. Yet, its approach is unique. Most notably, it centres on the significance of the Kabyle language and Zahra's creative and unique use of it - in the transmission of memory and culture from mother to daughter.

As was the case for El Madani, Sfaxi, and Benguigui, a key outcome for Sissani in making her documentary was the transmission of memory from mother to daughter and greater knowledge of her mother's life. Sissani, however, was not driven primarily by a desire to obtain this knowledge so as to come to a better understanding of her own identity or sense of self; rather, as she explains on her website, gaining insights into her mother, and her mother's life in France (which her mother considers a life in exile), was the goal in and of itself. In addressing her work (as a journalist and director), Sissani has said:

Most of my work revolves around immigration and exile. In truth, exile obsesses and fascinates me. It sticks to my skin, and always finds its way back through a small door. This time it was my mother who drove this. I let her become engulfed in it as I knew that the moment had come to ask her about these small slices of life, which I had never found the right time, or perhaps the courage, to ask her about. (2012) 
In my 2012 interview with her, Sissani revealed an additional driving force behind her decision to make this documentary and something that distinguishes her film from Mémoires d'immigrés (which aimed to fill a void in the collective memory of France and break a silence with regard to the history of Maghrebi migration to France): Sissani wanted to challenge and problematize common perceptions about Maghrebi migrant women in France - perceptions which, in her view, cannot be dissociated from the legacy of colonialism. She argued that they are characterized by ideas of submissiveness, illiteracy, and a lack of culture, and she cited the representations of women from the Maghreb in Philippe Faucon's 2001 feature film Samia, as a film that reinforces this idea (22 May 2012 interview). In Samia, first-generation women are depicted as victims of a patriarchal culture who do not seek to challenge traditional gender roles or their disempowered status. In fact, they try to impose these same roles on their daughters, who attempt to rebel against them.

In making a documentary about her mother, the rich heritage of the Kabyle culture and language, and her mother's poetic use of this language, Sissani hoped not only to provide a counterpoint to such perceptions, but also to promote the acceptance of children of immigrants in France by showing that they are not children of disempowered (post)colonial subjects; rather, they are descendants of people whose culture and language are rich in history and tradition (22 May 2013 interview). This idea is reinforced by the dedication that appears on-screen near the beginning of the film, which reads: 'To our parents, illiterate people of great culture. To us, children of immigration'. Integral to Sissani's project is the transmission of memory from mother to daughter, a 
process that is itself inextricably tied to the Kabyle language, since the large majority of the film is in Kabyle. These memories are accessible to the majority-ethnic spectators to whom the film is destined through the addition of subtitles.

The transmission of memories occurs in three key ways in Sissani's film: first, there is a transmission memory from mother to daughter that stems from question and answer sessions in Zahra's home. In order to put her mother at ease during these sequences, the director decided that she needed to be in front of the camera with her mother, so that Zahra would look at and speak to her, rather than the camera. Medium close-up shots of mother and daughter alternate with close-up shots of Zahra's face as she shares her thoughts and memories and recites poetry. The topics of discussion focus to a large extent on living in exile, language, Zahra's reverence for the Kabyle language and her refusal to learn French because she never wanted to stay in France and always thought she would return to Algeria. As in El Madani's documentary, a visit to the mother's country of origin is a key tool used to evoke the past in La langue de Zahra, as places and people serve to spark memories and discussions. Fatima and Zahra return to Zahra's village, and in the sequences filmed here, memories relating to Zahra are evoked through the interactions between Fatima, Zahra and other female family members. Fatima interviews her mother's sister, for example, in the presence of her mother, and the sister's words illuminate the circumstances surrounding Zahra's immigration to France (notably Zahra's inability to feed her family). Sissani also films her mother in group interactions with other women of her generation. In one sequence, Zahra sits in the middle of a semicircle of women as they speak of an experience they shared during the Algerian war of independence. They describe fleeing their village when the French military tried to keep 
them from voting. While Zahra's description of her sister's attempts to carry both her belongings and her child on her back provokes laughter from the women, other references to the war in this film are much more sober in tone. The poems that the women recite while they are interviewed in pairs evoke bombings, the 'dishonouring' of women, and the deaths of loved ones at the hands of the French. As noted above, the Algerian war is not discussed by the Maghrebi women in Benguigui's Mémoires d'immigrés, and thus its treatment in Sissani's film is significant. ${ }^{2}$ That said, Sissani did say that she was somewhat selective about which memories about the war were included in the film. According to the director, this was done out of respect for the privacy of the women and the intimacy of their village and because she realized that the women often forgot about the presence of the camera (22 May 2012 interview).

The third way in which the transmission of memory functions in La langue de Zahra is through the recitation of songs and poems in Kabyle. This film highlights the interconnectedness of memory and emotion with the Kabyle language and is unique in its foregrounding of female creativity and the Kabyle language and culture. Zahra tells her daughter that she and other women in her family (like many other Kabyle people) compose poetry notably during times of hardship, as a means of dealing with suffering or difficult situations. However, as she explains, she chose not to share all of her poems with her children because she did not want to make them unhappy, and they are painful for her to recite. The poetry that she recites in the film focuses on the pain of living in exile and in leaving one's family and country behind. As mentioned above, these themes are also evoked in Mémoires d'immigrés through songs on the soundtrack and archive images, but 
in Sissani's documentary the themes are rooted in a very personal narrative and are transmitted by way of the Kabyle language. ${ }^{3}$

With regard to the question of memory, La langue de Zahra is significant in three ways: first, it documents Zahra's ability to compose poetry and inscribe memories and her family heritage in language; second, it serves as a tool for the preservation and transmission of memory within the family. Zahra's daughters may speak the language (some more fluidly than others), but they do not recite or compose poetry. Finally, in preserving Zahra's language and memories in cinematic form - and adding subtitles Sissani is able to share them with the majority-ethnic audience in France. In its privileging of the specificity of the experiences of a Maghrebi migrant woman in France, Sissani's documentary - like the films of El Madani, Sfaxi, Kherfi, and Nini - sheds new light on the narrative of Maghrebi migration that is set forth in Benguigui's Mémoires d'immigrés.

\section{Conclusion}

The mother-daughter dynamic plays an invaluable role in the transmission of memory in each of the documentary films considered above, whether the transmission occurs directly between the mothers and their daughters, or in a more indirect manner between the daughter/director and the implied spectators. The mother-daughter relationship served to facilitate the filming process and the evocation of memory in significant ways. The impact of the daughters' knowledge of cultural codes, their mother's native language (in some but not all cases) and the bonds of trust shared with their mothers cannot be overlooked, nor can the influence of the daughters' own memories of their mothers, 
which are often used as starting points for discussion. Moreover, the mother-daughter bond gave the directors access to intimate and traditionally 'female' spaces in the home, such as the kitchen and bedroom, which served as the setting of many sequences and discussions. Finally, if not for the involvement of the daughters, some of the women would not have spoken openly - or have been featured at all - in the films. For example, Kherfi's presence reassured her mother's friends, and it was only because they knew her that they were willing to speak to her on camera (12 May 2012 interview). As noted above, Sfaxi chose not to work with a film crew because she realized that her mother was not speaking openly in front of other people (10 June 2010 interview). Finally, Sissani said that the filming of La langue de Zahra was greatly facilitated by the fact that the technicians who worked with her did not speak Kabyle, as it put her interviewees at ease and made them more willing to speak freely to Sissani (22 May 2012 interview).

In conclusion, I have endeavoured to show that while Benguigui's Mémoires d'immigrés is an important reference with regard to cinematic representations of Maghrebi migrant women in France in documentary form and undoubtedly helped pave the way for other films about Maghrebi migrants and their descendants in France - one could argue that Mémoires d'immigrés was a necessary event - the five 'motherdaughter' documentaries produced subsequent to it can be read as broadening the scope of Benguigui's work while diverging from it in key ways, notably by adopting approaches that privilege individual stories and bring to the fore new perspectives with regard to Maghrebi migration to France. These films deconstruct the notion that there was a collective Maghrebi migrant experience in France and reflect an idea expressed by Sissani during our discussion: she said that while there were definitely certain 
commonalities shared by most first-generation Maghrebis (notably their disadvantaged socio-economic position), 'there are as many immigrant stories as there are immigrants' (22 May 2012 interview). In foregrounding the diversity of experiences and memories of first-generation women, these films contribute to reshaping and challenging representations and common perceptions of Maghrebi women in France. The full impact

of these documentaries remains to be seen, however, given the relatively limited exposure of the films to large mainstream audiences in France, especially when compared to the visibility and notoriety enjoyed by Mémoires d'immigrés.

\section{References}

Altermédia (2013), ‘Altermédia’, http://www.altermedia.org/index.php?option=com_ content\&task=view\&id=81\&Itemid=176. Accessed 30 May 2013.

Benguigui, Y. (1997a), 'Yamina Benguigui', Nulle part ailleurs, Issy-les-Moulineaux: Canal+, 29 May. (1997b), Mémoires d'immigrés, l'héritage maghrébin, Suresnes: Bandits/Canal+.

Durmelat, S. (2000), 'Transmission and mourning in Mémoires d'immigrés: l'héritage maghrébin: Yamina Benguigui as "memory entrepreneuse", in J. Freedman and C. Tarr (eds), Women, Immigration and Identities in France (trans. J. R. Poynter and C. Tarr), Oxford: Berg, pp. 171-88. 
El Madani, R. B. (2003), Du côté de chez soi, Paris: LDR.

Filhon, A. (2009), Langues d'ici et d'ailleurs: Transmettre l'arabe et le berbère en France, Paris: Ined.

Kealhofer, L. (2011), 'Veiled voices in the films of Yamina Benguigui', Studies in French Cinema, 11:3, pp. 207-21.

Kherfi, Y. (2002), Mes voisines mes copines, Paris: Les Ateliers Varan.

Krim, R. (1997), Sous les pieds des femmes, Paris: SDP Films and Borromée Production.

(1998), 'La nuit du Ramadan', Le cercle des arts, Paris: France 2, 26 January.

McNeill, I. (2010), Memory and the Moving Image: French Film in the Digital Era, Edinburgh: Edinburgh University Press.

Nichols, B. (1991), Representing Reality: Issues and Concepts in Documentary, Bloomington: Indiana University Press.

Nini, S. (2007), 24 heures dans la Life de ma mère, Toulon: Aspect et Tandem. 
Sedira, Z. (2003), Mother, Father, and I (video installation), St. Louis: St. Louis Art Museum, October 2003

Sfaxi, D. (2003), À ma mère, Saint Denis: Altermédia.

Sissani, F. (2011), La langue de Zahra, Le Mans: 24 images.

(2012), ‘Mon parcours', http://lalanguedezahra.blogspot.com/p/monparcours 5381.html. Accessed 27 August 2012.

(2013), ‘Soutiens', http://lalanguedezahra.blogspot.com/p/remerciements.html. Accessed 31 May 2013.

Stora, B. (1998), La gangrène et l'oubli: La mémoire de la guerre d'Algérie, Paris: La Découverte.

Tarr, C. (2005), Reframing Difference: Beur and Banlieue Filmmaking in France, Manchester: Manchester University Press.

Tarr, C. and Rollet, B. (2001), Cinema and the Second Sex: Women's Filmmaking in France in the 1980s and 1990s, New York: Continuum.

\section{Contributor details}


Leslie Kealhofer is Assistant Professor of French at the University of Rhode Island, USA. Her recent publications include 'Maghrebi-French women in French téléfilms: Sexuality, gender, and tradition, from Leila née en France (1993) to Aïcha: les vacances infernales (2012)' (Modern and Contemporary France, 2013), “'Elle et moi, on est comme des sœurs": The dynamics of intercultural female friendship in Philippe Faucon's Dans la vie (2007)' (Expressions maghrébines, 2012), “'Raconter leur histoire, c'est faire entendre leurs voix": Un entretien avec Fatiha Benatsou' (The French Review, 2012), and 'Veiled voices in the films of Yamina Benguigui' (Studies in French Cinema, 2011).

\section{Contact:}

131 Swan Hall, Department of Modern and Classical Languages and Literatures, University of Rhode Island, 60 Upper College Rd, Kingston, RI 02881, USA. E-mail: 1kealhofer@uri.edu

Notes

\footnotetext{
${ }^{1}$ I would like to thank Margaret C. Flinn for bringing this to my attention.

${ }^{2}$ Memories of the Algerian war are evoked in a mother-daughter interview between artist Zineb Sedira and her mother in Sedira's video installation entitled Mother, Father, and I (2003), as well as in Rachida Krim's feature-length fiction film Sous les pieds des femmes (1997).

${ }^{3}$ For a sociological analysis of the transmission of the Arab and Berber languages from Maghrebi migrants to their children in France, see Filhon (2009).
} 